\title{
Publicidade e Propaganda: história, conceitos e trajetória de ensino
}

\author{
Undergraduation in Advertising: history, concepts and teaching trajectory \\ Publicidad y Propaganda: historia, conceptos y trayectoria de enseñanza
}

Recebido: 01/11/2021 | Revisado: 08/11/2021 | Aceito: 14/11/2021 | Publicado: 24/11/2021

\author{
Suelen Miyuki Alves Guedes \\ ORCID: https://orcid.org/0000-0002-5994-4001 \\ Universidade Federal do Pará, Brasil \\ E-mail: suelen_miyuki@hotmail.com \\ Maria Ataide Malcher \\ ORCID: https://orcid.org/0000-0003-4687-1840 \\ Universidade Federal do Pará, Brasil \\ E-mail: aataide@ufpa.br
}

\begin{abstract}
Resumo
O ensino de graduação em Comunicação Social - Habilitação em Publicidade e Propaganda no Brasil surgiu na segunda metade do século XX, a partir de demandas estabelecidas principalmente pelo mercado midiático. Nesse contexto, realizamos reflexões sobre a história, os conceitos e os caminhos da Publicidade e da Propaganda no Brasil, assim como sua trajetória no Ensino Superior, para entender a formação na área. A partir dessa contextualização, esse trabalho tem como objetivos estudar e entender as dinâmicas que envolvem a constituição da Publicidade e Propaganda no país e como esse processo gerou/gera reflexos no ensino e na formação dos estudantes dessa área. O estudo foi realizado por meio de pesquisa bibliográfica e documental, a partir de uma abordagem qualitativa. Dentre as principais discussões empreendidas está a reflexão sobre a separação ainda presente entre as dimensões teórica e prática na Comunicação e como essa divisão tem relação direta na formação em Publicidade e Propaganda. Todas essas questões têm implicações no ensino, cujo direcionamento acaba seguindo rumos predominantemente mercadológicos, muitas vezes até instrumentais, por conta de toda a relação histórica, financeira e cultural com o mercado.
\end{abstract}

Palavras-chave: Ensino; Comunicação; Publicidade e propaganda; Ensino superior; Teoria e prática.

\begin{abstract}
The teaching of undergraduation in Social Communication, with a minor on Advertising, emerged in the second half of the $20^{\text {th }}$ century from demands established mainly by the media market. In this context, we reflected on the history, the concept and the paths of Advertising in Brazil, as well as its trajectory in Higher Education, in order to understand training in this area. From this contextualization, this paper aims to study and understand the dynamics involving the constitution of Advertising in the country, and how this process (has) generated reflections on the teaching and training of students in this area. The study was carried out through bibliographical and documentary research, from a qualitative approach. Among the main discussions undertaken is the reflection on the separation - still present between the theoretical and practical dimensions in Communication and how this division is directly related to training in Advertising. All these issues have implications on teaching, whose directions end up following predominantly market paths, often even instrumental, due to all the historical, financial and cultural relationship with the market.
\end{abstract}

Keywords: Teaching; Communication; Advertising; Higher education; Theory and practice.

\section{Resumen}

La formación de grado en Comunicación Social - Publicidad y Propaganda en Brasil surgió en la segunda mitad del siglo XX, a partir de demandas establecidas principalmente por el mercado de los medios de comunicación. A partir de esta contextualización, reflexionamos sobre la historia, los conceptos y los caminos de la Publicidad y la Propaganda en Brasil, así como su trayectoria en la Educación Superior, para entender la formación en el área. A partir de esa contextualización, este trabajo se propone estudiar y comprender la dinámica que implica la constitución de la Publicidad y la Propaganda en el país y cómo este proceso generó/genera reflejos en la enseñanza y formación de los estudiantes en esta área. El estudio se realizó mediante una investigación bibliográfica y documental, desde un enfoque cualitativo. Entre las principales discusiones aprendidas está la reflexión sobre la separación que aún existe entre las dimensiones teórica y práctica en la Comunicación y cómo esta división tiene una relación directa con la formación en Publicidad y Propaganda. Todas estas cuestiones tienen implicaciones en la enseñanza, en que su orientación acaba siguiendo caminos predominantemente mercadológicos, muchas veces incluso instrumentales, debido a toda la relación histórica, financiera y cultural con el mercado.

Palabras clave: Enseñanza; Comunicación; Publicidad y propaganda; Enseñanza superior; Teoría y práctica. 


\section{Introdução}

Quem conclui a graduação em Medicina é comumente conhecido como médico, em Arquitetura como arquiteto, em Sociologia como sociólogo e em Publicidade e Propaganda como publicitário. No entanto, a Lei № 4.680, de junho de 1965, que regulamenta a atividade de Publicidade e Propaganda prevê duas profissões diferenciadas: o publicitário e o agenciador de propaganda. O primeiro é aquele que exerce funções de natureza técnica em agências de propaganda, veículos de divulgação ou outras empresas no âmbito da produção de propaganda. Já o segundo, associado aos veículos de divulgação, é responsável por encaminhar o material produzido para veiculação (Brasil, 1965).

Segundo Gomes (2001) e Gonçalez (2009), a principal diferença entre a Publicidade e a Propaganda está nos objetivos. A Publicidade está associada à promoção de bens de consumo e serviços buscando torná-los conhecidos e efetivar uma compra, ou seja, tendo um interesse essencialmente comercial. Já a Propaganda tem um caráter ideológico, tenta convencer ou doutrinar o comportamento do indivíduo, seja em uma perspectiva política, religiosa, social ou econômica (Gomes, 2002). No entanto, ambas as práticas são bem mais complexas que isso, por diversos fatores, seja pelo capital financeiro e simbólico que carregam consigo, seja pelo papel de construtoras das relações sociais e culturais na sociedade.

Assim, não podemos concebê-las de maneira restrita a um caráter puramente mercadológico ou político. Esses processos habitam todos os âmbitos das nossas vidas, interagimos a partir delas, estabelecemos hábitos de consumo que definem quem somos e o que queremos. Suas dinâmicas dão significado ao nosso cotidiano, à relação em sociedade e às práticas culturais.

O surgimento da Propaganda também tem suas origens vinculadas à religião. No período de domínio da Igreja Católica, século V a XV, ela se utilizava da Propaganda para estabelecer poder político e ideológico. Mas foi no momento de crise que essa atividade se firmou. Com a rápida difusão das ideias luteranas, a Igreja Católica se sentiu ameaçada e institucionalizou a Propaganda por meio da Ordem dos Predicadores que tinha como objetivo difundir os ideais católicos, como forma de contra-atacar a influência do luteranismo e, ao mesmo tempo, expandir o catolicismo entre os não fiéis (Gomes et al., 1998).

As organizações religiosas eram, portanto, as principais difusoras ideológicas desse período. O clero era detentor de todos os livros, o centro de conhecimento, e o único, junto com a nobreza, habilitado a ler e a escrever. Dessa forma, utilizavase de estratégias para educar a sociedade por meio da religião. Assim, a propaganda acabou assumindo um caráter de divulgação do conhecimento religioso tanto para os fiéis da Igreja, quanto para aqueles que seriam convertidos à ideologia cristã (Muniz, 2004). Portanto, essa prática ligada à doutrina religiosa já tem alguns séculos de tradição.

No campo da Comunicação Social, a Propaganda

Consiste num processo de disseminação de idéias através de múltiplos canais com a finalidade de promover no grupo ao qual se dirige os objetivos do emissor, não necessariamente favoráveis ao receptor; implica, pois, um processo de informação e um processo de persuasão. Podemos dizer que propaganda é o controle do fluxo de informação, direção da opinião pública e manipulação - não necessariamente negativa - de conduta e, sobretudo, de modelos de conduta (Gomes et al., 1998).

Nesse sentido, podemos perceber que essa prática está intimamente ligada à questão do convívio em sociedade, seja a partir de modelos de conduta, o que é socialmente aceito ou não ou a defesa de ideologias em todos os âmbitos da vida. A partir do século XX, com o desenvolvimento da tecnologia, foi possível consolidar a propaganda política como um canal de comunicação com a sociedade, principalmente através dos meios massivos: jornal e rádio em um primeiro momento, e posteriormente, de maneira mais ampla, com a televisão. Com inserções estratégicas nesses meios massivos de comunicação, a propaganda política chega às casas de milhões de brasileiros. Como forma de legitimar sua entrada e garantir sua permanência 
nesses meios, muitos movimentos políticos foram realizados. Destaque para o horário obrigatório no rádio, por meio da Hora do Brasil ${ }^{1}$ e inserção na televisão com o horário eleitoral gratuito e, em períodos de eleição, para os debates feitos pelas emissoras.

Por outro lado, a Publicidade é definida como atividade em que bens de consumos e serviços são ofertados, com o objetivo de convencer outras pessoas a adquiri-los. Essa prática existe desde que o homem começou a produzir mais do que era necessário e criou formas de convencer o outro a adquirir. Ao longo da história da civilização, em vários momentos, utilizou-se essa técnica de comunicação para reforçar (antigos) ou criar (novos) hábitos de consumo (Gomes et al., 1998).

Até a Idade Média, a Publicidade era praticada por comerciantes e mercadores que anunciavam, por meio de ruídos, gritos e gestos, as suas mercadorias. Como as casas não tinham número e as ruas não eram identificadas, foi nessa época que surgiram os símbolos para demarcar determinado estabelecimento, o embrião do que hoje são as marcas e os logotipos. Por exemplo, um desenho de cabra representava um local que vendia leite (Muniz, 2004).

Foi no século $\mathrm{XV}$, com a invenção da imprensa mecânica por Gutenberg que a Publicidade iniciou uma etapa importante da sua história. A partir disso, passou a ter grande inserção no meio impresso, seja por meio de cartazes que começaram a se popularizar, seja em inserções em periódicos, principalmente nos jornais.

O marco na história da Publicidade foi a Revolução Industrial, na qual começou uma produção em massa e fomentou o aumento do consumo. Antes desse período, os anúncios eram essencialmente informativos, a partir de então, a mensagem publicitária começou a adquirir um caráter mais sugestivo e persuasivo. As condições econômicas e sociais colaboraram para o desenvolvimento da atividade publicitária. Os comerciantes precisavam se comunicar com um público que se ampliava cada vez mais, devido ao crescimento demográfico vivenciado nesse período e se organizava espacialmente de forma mais dispersa, fazendo emergir novas formas de comunicação. Foi nesse cenário que passamos de uma sociedade simples para uma sociedade complexa, ou seja, uma sociedade em rede como discute Castells (1999). Diante disso, de forma estratégica, os empresários passaram a utilizar esses meios para entrar em contato com os potenciais consumidores dos seus produtos e serviços e estabelecer, assim, hábitos de consumo (Gomes et al., 1998).

Com o decorrer do tempo, dos avanços tecnológicos e com a consolidação de uma indústria cultural ${ }^{2}$, a Publicidade foi ganhando novos espaços como rádio, televisão e internet, e passou a estar presente também nas ruas por meio de outdoors, busdoors, empenas ${ }^{3}$ e outras peças de comunicação visual. A linguagem também foi se transformando, adquirindo um tom mais descontraído e subjetivo. É possível percebermos que em todos os meios massivos de comunicação a Publicidade está sempre presente, atuando de maneira efetiva em suas dinâmicas.

A partir desse breve histórico que fizemos sobre a Publicidade e Propaganda, evidenciando que são duas práticas diferentes entre si, precisamos retomar a lei anteriormente citada para iniciarmos uma discussão sobre essas duas atividades. Nesse sentido, podemos constatar que a lei prevê duas possibilidades de atuação profissional, o publicitário e o agenciador de propaganda. No entanto, o ofício do agenciador de propaganda é pouco conhecido. Essa atividade era comum na época em que a regulamentação da profissão foi criada, em 1965, mas ao passar do tempo ela foi adquirindo outras funções e acabou desaparecendo o profissional com essa denominação. Ou seja, temos a defasagem na lei que institui uma atividade profissional, que na prática, não existe mais.

\footnotetext{
${ }^{1}$ Programa de rádio, com uma hora de duração, criado pelo Estado Novo em 1930. O programa de dedica a anunciar as obras do governo e exaltar o então presidente, Getúlio Vargas. O programa existe até hoje, denominado atualmente de A voz do Brasil, com uma outra roupagem, oferecer notícias de utilidade pública aos cidadãos e informar decisões dos Poderes Legislativo e Judiciário.

${ }^{2}$ Trataremos com maior destaque esse conceito mais adiante.

${ }^{3}$ Grandes placas de publicidade que são instaladas em fachas laterais cegas de edifícios.
} 
Para além dessa questão, o mais preocupante é o fato de não se conhecer as especificidades dessas duas esferas e o quanto essa falta de clareza e incompreensão limita a Publicidade e Propaganda, fazendo com que sejam encaradas de maneira superficial, não como um complexo processo comunicacional.

Um outro ponto é a discussão que reside no fato do equívoco no uso dos termos Publicidade e Propaganda no Brasil, em que ambas são abordadas como sinônimas. Nesse sentido, podemos destacar, por exemplo, as agências que carregam em seu nome "Agência de Publicidade" ou "Agência de Propaganda" de maneira aleatória, sem distinguir uma atividade e outra. Com isso, é comum encontrarmos agências de propaganda produzindo trabalhos publicitários e vice e versa, ou até mesmo, atuando nas duas vertentes, mas tendo o nome de apenas uma atividade.

Esse mesmo problema pode ser notado também em documentos oficiais do país, como por exemplo, a referida lei de regulamentação da profissão, a qual podemos observar que ao definir a atividade do publicitário, a lei aponta que ele pode atuar em agências de propaganda quando o mais coerente seria em agências de publicidade. Diante disso, temos uma lei que além de não distinguir uma prática e outra, não contempla o fazer Propaganda, apenas as atividades publicitárias são mencionadas. Levando-se em consideração que a denominação do agenciador de propaganda não é empregada de maneira adequada, o mais coerente seria ser intitulado agenciador de publicidade, já que esse profissional era responsável por encaminhar o material produzido para veiculação, na maioria das vezes, anúncios com fins comerciais, direcionados ao jornal, rádio ou televisão.

De maneira mais recorrente, podemos perceber a mesma confusão nas referências bibliográficas sobre o assunto, que utilizam os termos como similares, sem qualquer distinção conceitual. De acordo com Gomes (2002), esse erro é comum no Brasil devido aos problemas de tradução. As primeiras publicações sobre o assunto abordavam duas práticas distintas, no entanto, no processo de tradução para o português, foram retratadas como iguais, o que acabou gerando uma confusão, que perdura até hoje, nas denominações e nos conceitos. Gomes (2002) indica ainda que o fato de ambas se utilizarem de linguagens, técnicas e estratégias semelhantes faz com que o problema na definição e no uso dos conceitos permanecesse ao longo do tempo.

Diante disso e partindo do pressuposto de que são duas práticas distintas, levantamos algumas questões que nos inquietam com relação ao assunto: Onde fica a Propaganda nessa situação? Por que não formamos publicitários e propagandistas? Ou publicitários e propagadores? E mais importante, diante dessa problemática, como se dá a formação do estudante?

Acreditamos, porém, que a razão pela qual esse equívoco de nomenclaturas e conceitos e, sobretudo, a maior ênfase e reconhecimento da Publicidade em detrimento da Propaganda, tanto no mercado quanto na academia e na formação do aluno de maneira geral, se dá não só por essas questões levantadas por Gomes (2002), como também por motivos históricos que remontam ao próprio processo de formação da cultura brasileira, em que a atividade publicitária teve papel preponderante. Dessa forma, este artigo tem como objetivo estudar e entender as dinâmicas que envolvem a constituição da Publicidade e Propaganda no Brasil e como esse processo gerou/gera reflexos no ensino e na formação dos estudantes dessa área. Para isso, é imprescindível que nos voltemos para o período de formação do mercado de consumo cultural do país.

\section{Metodologia}

O estudo foi realizado a partir de pesquisa bibliográfica e documental. Segundo Gil (1999), a pesquisa bibliográfica é baseada na consulta de materiais já elaborados, principalmente livros e artigos científicos. Essa metodologia é estratégica, pois permite que a investigação consiga ter uma ampla cobertura de análise com base em estudos anteriores e ter informações de pesquisas já realizadas. 
Como discute Pimentel (2001), a pesquisa documental é um estudo baseado em documentos como material primordial, na qual são realizadas análises, organização e interpretação dos dados conforme os objetivos e a proposta da investigação.

Essa pesquisa tem uma abordagem qualitativa que de acordo com Creswell (2007) se diferencia da quantificativa, pois emprega diferentes alegações de conhecimento, estratégias de investigação e métodos de coleta e análise de dados. Os procedimentos qualitativos se baseiam em dados de texto e imagem, têm passos únicos na análise de dados e usam estratégias diversas de investigação, não sendo uniformes (Creswell, 2007).

\section{A consolidação da Indústria Cultural no Brasil}

Falar em cultura brasileira é refletir sobre a trajetória política e social do país. A emergência de uma indústria cultural aconteceu de forma tardia no Brasil, com isso as reflexões sobre a cultura de mercado ocorreram de forma atrasada e diferenciada se comparada aos países desenvolvidos. Martín-Barbero (2009) denominou esse processo de "modernidade nãocontemporânea", que se afasta da ideia de atraso constitutivo e tem duas perspectivas. Uma que parte do princípio de que os países latino-americanos foram constituídos histórico e socialmente de forma que escapam à lógica do desenvolvimento capitalista. E outra, que concebe a modernização nesses países como recuperação do tempo perdido, em que se busca um desenvolvimento definitivo para subitamente se tornar moderno, que evidentemente não se efetiva de imediato e gera contradições.

A consolidação de um mercado de bens culturais teve especificidades no Brasil e só ocorreu de fato a partir da década de 60, do século XX. As décadas anteriores viviam apenas o ensaio das transformações que viriam a acontecer no país. Na Europa e nos Estados Unidos, esse processo se deu em um período anterior e de forma bem diferenciada.

O século XIX se caracteriza pela emergência de duas esferas distintas: uma de circulação restrita, vinculada à literatura e às artes, outra de circulação ampliada, de caráter comercial. O público se encontra desta forma cindido em duas partes: de um lado, uma minoria de especialistas, de outro, uma massa de consumidores. Esta oposição não deixa de colocar em conflito os atores desses dois campos sociais. Por isso vamos encontrar entre os artistas, os escritores, as vanguardas, as primeiras críticas em relação à chamada cultura das massas (Ortiz, 1991, p. 25).

Ortiz (1991) ressalta que no Brasil esse cenário é bem diferente, o quadro cultural brasileiro não é igual à realidade europeia ou norte-americana. Não há diferenciação entre um polo de produção restrita e outro de produção ampliada, pois o Brasil ainda era um país periférico e o capitalismo existente era muito frágil, não havia um mercado de bens simbólicos. "Isso significa uma fraca divisão do trabalho intelectual e uma confusão de fronteiras entre as diversas áreas culturais" (Ortiz, 1991, pp. 25-26).

Diante disso, as contradições entre uma cultura erudita e outra de mercado não se manifestaram de forma antagônica no Brasil. Essa especificidade originou uma dupla consequência: uma positiva que abre espaço de criação que em alguns períodos foi aproveitado por determinados grupos culturais; outra de caráter mais restritivo, no qual os intelectuais passam a atuar dentro de uma lógica comercial e apenas reproduzem o que já está estabelecido, e por isso, não desenvolvem uma visão crítica em relação ao tipo de cultura que produzem (Ortiz, 1991).

Ortiz (1991) evidencia que na virada do século XIX para o século XX, o Brasil vivia em pleno vapor o espírito da Belle Époque. A remodelação urbana das cidades, a valorização do chique europeu, a agitação dos novos tempos, a eletricidade nas casas e nas ruas eram características desse período. O país passava por transformações sob o signo do moderno e se espelhava nos valores europeus, com o desejo de fazer do Brasil sua imagem e semelhança. 
Por outro lado, destoando desse ar de modernidade, nesse mesmo cenário, havia a presença de favelas e o peso de uma herança colonial de exploração, uma imagem que colocava em contraposição o ideal moderno que a sociedade brasileira perseguia e queria transmitir, contradições que caracterizam a "modernidade não-contemporânea" (Martín-Barbero, 2009).

Nesse sentido, eu diria que a noção de modernidade está 'fora de lugar' na medida em que o Modernismo ocorre no Brasil sem modernização. Não é por acaso que os críticos literários têm afirmado que o Modernismo da década de 20 'antecipa' mudanças que irão se concretizar somente nos anos posteriores. Antecipação que denuncia esse hiato, a inadequação de certos conceitos aos tempos em que são enunciados. Não se trata, porém, de uma previsão, de uma genialidade imanente ao homem de arte; o descompasso é um elemento da sociedade brasileira periférica (Ortiz, 1991, p. 32).

Como discute Versiani e Suzigan (1990), é somente a partir da década de 1940 que o país começa de fato a se modernizar. Até 1939, os setores voltados à produção de bens de consumo não-duráveis, principalmente do setor agrário, refletiam ainda um peso preponderante na economia brasileira. Nas duas décadas seguintes, que abrangem parte do período do Plano de Metas, a situação se modifica. O rápido crescimento do setor industrial começa a mudar o cenário anterior, as indústrias Metalúrgica, Mecânica, de Material e Transporte avançam, configurando o desenvolvimento da produção de bens de consumo durável e de produtos intermediários, em particular a indústria siderúrgica.

Nesse sentido, a sociedade brasileira se moderniza em diferentes setores, vivencia "o crescimento da industrialização e da urbanização, a transformação do sistema de estratificação social com a expansão da classe operária e das camadas médias" (Ortiz, 1991, p. 38). É nesse contexto de desenvolvimento do país que os antigos meios como a imprensa, rádio e cinema são redefinidos e a televisão e o marketing iniciam seu processo de ascensão, dando início aos diversos ramos de produção e difusão de massa (Ortiz, 1991).

Não obstante, apesar do dinamismo da sociedade brasileira no pós-guerra, percebemos que ele se insere no interior de fronteiras bem delimitadas. ... Não é por acaso que os economistas chamam esta fase de 'industrialização restringida', isto é, o movimento de expansão do capitalismo se realiza somente em determinados setores, não se estendendo para a totalidade da sociedade. Em termos culturais temos que o processo de mercantilização da cultura será atenuado pela impossibilidade de desenvolvimento econômico mais generalizado. Dito de outra forma, a 'indústria cultural' e a cultura popular de massa emergente se caracterizam mais pela sua incipiência do que pela sua amplitude (Ortiz, 1991, p. 45).

O problema da incipiência e profissionalização atinge todos os setores do mercado cultural. Eram tempos de precariedade na infraestrutura em que os atores, diretores, publicitários, cineastas e técnicos trabalhavam na base do improviso. A produção cultural era marcada pelo amadorismo. Apesar da má-estruturação, os objetivos empresariais da época eram claros. Nessa fase, na qual tudo ainda está por se construir, a iniciativa individual é parte essencial para o funcionamento, mesmo que não ideal, dessa estrutura (Ortiz, 1991). Figuras como Assis Chateuabriand, Roberto Marinho entre muitos outros, foram fundamentais nesse processo e marcaram a história do Brasil de forma indiscutível. A partir dos resultados das iniciativas individuais, por exemplo, herdamos todo nosso sistema de mídia, com todas as suas potencialidades e restrições. Questões que são extremamente relevantes e merecem discussões aprofundadas em outra oportunidade.

Se por um lado a precariedade provoca a improvisação e, por isso, gera um caráter amador nas produções, por outro, possui uma dimensão que direciona para a liberdade criativa. Nesse sentido, todos os profissionais envolvidos têm a liberdade de usar a imaginação, transformar a linguagem e criar novas dinâmicas nos meios de comunicação.

De acordo com Ortiz (1991), nas décadas de 1960 e 1970 é que se consolida de fato o mercado de bens culturais no Brasil. Nesse período, ocorreu um desenvolvimento diferenciado nos diversos setores ao longo do tempo. A televisão se 
concretiza como veículo de massa em meados dos anos 1960 e o cinema nacional em 1970, cada meio foi se estabelecendo em períodos distintos e de maneira diferenciada.

O marco desse período foi o golpe militar de 1964. A sociedade brasileira passou por transformações estruturais tanto no âmbito político quanto econômico. Na dimensão política, o Estado militar tinha como características a repressão, censura, prisões e exílios. Já na dimensão econômica, o governo aprofundou medidas que permitiram a reorganização da economia brasileira, consolidando o "capitalismo tardio" (Ortiz, 1991) e inserindo o país no processo de internacionalização do capital. Com isso, possibilitou não só o crescimento industrial e do mercado interno de bens materiais, como também fortaleceu a produção de cultura e o mercado de bens culturais.

O que caracteriza a situação cultural nos anos 60 e 70 é o volume e a dimensão do mercado de bens culturais. Se até a década de 50 as produções eram restritas, e atingiam um número reduzido de pessoas, hoje elas tendem a ser cada vez mais diferenciadas e cobrem uma massa consumidora. Durante o período que estamos considerando, ocorre uma formidável expansão, a nível de produção, de distribuição e de consumo da cultura; é nesta fase que se consolidam os grandes conglomerados que controlam os meios de comunicação e da cultura popular de massa (Ortiz, 1991, p. 121).

A implantação de uma indústria cultural não seria possível sem os avanços da publicidade, que é a base sustentadora da indústria da cultura ao manter financeiramente, por meio da verba publicitária, toda a lógica que rege os meios de comunicação massivos no Brasil. Nesse sentido, modificou-se o padrão de relacionamento com a cultura, uma vez que estava ligado a interesses comerciais, um dos fatores que fizeram com que, como indica Ortiz (1991), não houvesse uma discussão mais profunda sobre o que se estava produzindo. Nesse cenário, a publicidade adquire papel relevante na sociedade, tanto em uma perspectiva econômica quanto social e construtora de identidade, tornando-se a força motriz dessa estrutura. Em uma sociedade capitalista, o bem mais precioso é o capital, não só econômico como também simbólico, e a Publicidade atua a partir de ambos.

A concretização de um mercado de consumo e a formação cultural do Brasil só pode ser efetivada devido à Publicidade ter um importante papel econômico, como também social e cultural na sociedade. Essa relação corresponde a via de mão dupla, em que tanto a Publicidade faz parte da construção da indústria cultural, quanto a indústria cultural constitui e direciona a Publicidade. É nesse cenário que o ensino de Publicidade e Propaganda se institucionalizou no país, a partir da consolidação do consumo de bens culturais e das demandas do mercado.

A Propaganda no Brasil, apesar de não ter tido a mesma visibilidade que a Publicidade, desempenhou também um papel central na trajetória do país. A sua utilização como instrumento de dominação e exercício de poder não é uma prática recente, vimos sua institucionalização na Idade Média, por meio da Igreja Católica, e como Vaz (2002) aponta, vários outros governantes ao longo da história se apropriaram dessa prática para estabelecer e manter o poder em diversas sociedades. Com o avanço dos meios de comunicação e o surgimento da imprensa, rádio, cinema e televisão os grandes estadistas sempre estiveram lado a lado desses meios para se comunicar com o povo.

No século XVII na França, Luis XIV, conhecido como Rei Sol, fazia divulgação de sua imagem através de moedas, estátuas e quadros. Benito Mussolini, na década de 1930 e começo da década de 1940, conseguiu sustentar o fascismo com o apoio popular durante muito tempo, devido ao estratégico e bem executado uso de propaganda ideológica. Vladimir Lenin, na primeira metade do século XX, também contava com a propaganda como uma ferramenta para provocar a agitação das massas e o apoio do povo para manter os ideais comunistas. Mas foi Hitler que utilizou como ninguém a propaganda e os meios de comunicação massivos para conquistar a população e legitimar sua ideologia nazista (Vaz, 2002).

No Brasil, quem primeiro percebeu o poder da propaganda para manipulação ideológica da população foi Getúlio Vargas, que usou massivamente o rádio e o cinema como os principais meios de falar ao povo, que se tornaram 
grandes aliados do poder na transmissão das mensagens num país de dimensões tão grandes como o Brasil. De lá para cá, os governos foram aprimorando e afinando o seu discurso junto à população (Vaz, 2002, p. 1).

Posterior à Era Vargas, os governos militares que se seguiram foram responsáveis pelo período de maior esforço coletivo de comunicação massiva da nossa sociedade. Tanto as agências privadas, financiadas pelo empresariado da época, quanto as agências estatais de propaganda, apresentavam o mesmo discurso ufanista e desenvolvimentista em suas ações de comunicação. Pregavam a ordem, a moral e os bons costumes vigentes que davam conforto social que interessava o governo e as classes dominantes (Lacerda, 2008).

Ao observarmos a propaganda oficial do governo militar no Brasil nas décadas de 1960 e 1970, verificaremos que às vezes de forma sutil, outras, de modo mais explícito, os militares criaram uma verdadeira rede de comunicação a fim de implantar suas idéias e posições (Lacerda, 2008, p. 68).

Enquanto a publicidade assumiu um papel econômico e simbólico no Brasil, e esteve intimamente ligada ao processo de consolidação da indústria cultural no país, a propaganda esteve presente na alta cúpula do governo, auxiliando a elite a manter o poder. Nesse sentido, como aponta Vaz (2002), entender o processo de comunicação no Brasil é entender o poder, em suas diversas formas.

\section{Resultados e discussão}

Nesse sentido, é importante não apenas entender como o governo foi conduzido nessa época, mas também perceber os seus desdobramentos e analisar os rumos que a sociedade brasileira seguiu. Dessa forma, podemos observar que não por acaso, por exemplo, foram implementados nesse período nos cursos de nível superior os currículos mínimos, obrigatoriedades impostas pelo governo nos cursos de graduação, principalmente por meio de exigências de determinadas disciplinas, que no decorrer dos governos militares ficavam cada vez mais restritivos, visando ter maior controle sobre o que se ensinava nas universidades.

\subsection{O ensino de Publicidade e Propaganda}

O ensino de Comunicação passou por diversas transformações durante os governos militares, tivemos vários currículos mínimos implantados em curtos espaços de tempo. Isso porque, de maneira mais direta e específica, o governo sabia que a comunicação era uma "faca de dois gumes": era utilizada tanto para legitimação e permanência no poder, quanto representava uma ameaça, pois poderia ser usada para questioná-lo.

Pedrini e Malusá (2019) apontam que historicamente o ensino de Publicidade e Propaganda, no século XX, ocorreu em três fases distintas: de 1900 a 1930 na qual o aprendizado se dava pelo o autodidatismo; na década de 1930 com o momento em que as agências de publicidade se tornam escolas de formação com os programas de trainees; de 1940 a 1960 com o desenvolvimento dos primeiros cursos profissionalizantes e superior na área, nos quais o corpo docente deveria ser formado por profissionais atuantes no mercado de trabalho.

Antes do surgimento das escolas de Comunicação no Brasil, o aprendizado de Publicidade e Propaganda acontecia por meio da prática, os profissionais apareciam como uma "geração espontânea" e suas atividades eram voltadas para os anúncios classificados das publicações da época (Martensen, 1990). Ou seja, as demandas foram aparecendo e as pessoas foram aprendendo fazendo, em processos autodidatas, assim surgiram os primeiros profissionais. Só com a expansão da atividade e a sua legitimação na sociedade que se começou a pensar em seu ensino, primeiro com cursos de curta duração e depois no Ensino Superior. Essa origem pode representar um dos fatores do forte apelo prático no ensino de Publicidade e Propaganda. 
Como evidencia Gomes (2007), o ano de 1914 foi marcante para a história da Publicidade no Brasil. Em maio desse ano, foi criada a primeira agência de publicidade do país: a Castaldi e Bennaton, mais conhecida como A Eclética. Já em 1926, a General Motors, para potencializar a venda de seus automóveis, instalou seu Departamento de Publicidade no Brasil nos moldes do padrão norte-americano, país de origem da empresa, que já possuía história no setor publicitário. Com isso, a empresa trouxe experiências e contribuiu para a formação inicial dos novos profissionais, a partir do ensino prático no sistema de trainee, que consiste em um curso completo no qual a pessoa participa de todos os setores da agência, por meio de estágios.

De uma maneira geral, os profissionais de comunicação aprenderam as atividades na prática, sejam nos jornais, agências, rádio ou televisão. Apenas após a sua consolidação no mercado é que a universidade se volta para o ensino da Comunicação, mais por uma questão de demanda e pressão da sociedade, do que por interesse de estudar e pesquisar essa nova área.

Há uma relação direta, do ponto de vista histórico, entre a formação de quadros para atuar na indústria da comunicação e o desenvolvimento da própria indústria. Nesse sentido, quero mostrar que a universidade brasileira teve um papel de omissão em relação a essas novas atividades que emergem na sociedade. Ao invés de a universidade se antecipar para estudar esses fenômenos e, ao mesmo tempo, começar a formar quadros qualificados, a universidade vem a reboque (Marques De Melo, 1992, p. 61).

De acordo com Pinho (1998), com as crescentes demandas por formação em Publicidade e Propaganda, em 1951 surge a iniciativa pioneira da criação da Escola de Propaganda do Museu de Arte de São Paulo, iniciando assim, o ensino formal em Publicidade e Propaganda, mesmo não sendo reconhecido pelo Ministério da Educação e Cultura ${ }^{4}$ como curso de nível superior. Foi apenas em 1978 que o curso obteve seu reconhecimento.

Essa instituição ganhou autonomia e passou por algumas transformações ao longo do tempo, hoje é conhecida como Escola Superior de Propaganda e Marketing (ESPM), referência nessa área no Brasil. O curso ofertado na época de sua implantação priorizava o ensino prático da Publicidade e Propaganda.

O curso tinha duração de dois anos e as matérias que faziam parte do currículo eram: Psicologia, Elementos da Propaganda, Técnica de Esboço (Layout), Arte-Final, Produção e Artes Gráficas, Redação, Rádio-Cinema-Televisão, Mídia, Estatística e Pesquisa de Mercado, Promoção de Vendas e, ainda, atividades extracurriculares como visitas técnicas profissionais a veículos, anunciantes e fornecedores, aproximando, por meio dessas iniciativas, a escola e o mercado. É imprescindível lembrar que nessa época havia uma crescente demanda do mercado por mão-de-obra qualificada (Vitali, 2007, pp. 18-19).

O corpo docente era composto por experientes e famosos publicitários: Rodolfo Lima Martensen, Renato Castelo Branco, Antonio Nogueira, Geraldo de Souza Ramos entre outros. Nessa seleção, a prioridade era o conhecimento prático das disciplinas, mais do que as habilidades didáticas, pois o crescente mercado necessitava de capacitação profissional para o fazer publicitário e foi nessas circunstâncias que o curso foi implementado no país.

Por conta da necessidade de profissionais qualificados para suprir as exigências do mercado, a Escola de Propaganda recebeu apoio dos anunciantes da época que entenderam a importância da formação de recursos humanos para melhorar o setor publicitário e, consequentemente, beneficiar as suas empresas.

Podemos perceber que a origem do ensino de Publicidade e Propaganda está ligada a uma necessidade/demanda do mercado em ter à sua disposição recursos humanos qualificados. Dessa forma, a estrutura do curso foi concebida para cumprir obrigações mercadológicas, de maneira rápida (curso de dois anos de duração) e voltada para o fazer publicitário.

\footnotetext{
${ }^{4}$ Nesse período, os atuais Ministério da Educação (MEC) e Ministério da Cultura (MinC) eram integrados, com a denominação de Ministério da Educação e Cultura.
} 


\subsection{O descompasso no ensino de Publicidade e Propaganda}

Gomes (2002) discute que o ensino de Comunicação no Brasil tem como base dois modelos de abordagem. De um lado o modelo europeu que se caracteriza pela crítica, com maior preocupação pela pesquisa social e as questões ideológicas. O pensamento europeu percebe a comunicação como uma forma de conhecimento da realidade, que muitas vezes, tem a perspectiva da manipulação da população através dos meios de comunicação. Nesse sentido, essas atividades têm um papel central enquanto instrumento mediático. Por outro lado, tem também como referência o modelo norte-americano, influenciado pelas correntes Funcionalista, da Cibernética e da Teoria da Informação que entende a comunicação como uma informação transmitida entre sujeitos. Esse modelo é o que usa as mais sofisticadas pesquisas sobre estilo de vida e comportamento do consumidor, e por conta dos acontecimentos históricos e da hegemonia dos Estados Unidos se impôs em quase todo o mundo.

Mais do que a adoção de um modelo ou outro, é importante que se trabalhe tanto a escola americana funcionalista quanto a escola europeia crítica, e mais que isso, que se problematize a questão do receptor, pois, em ambas as perspectivas, ele é coadjuvante, seja como o alvo a ser atingido em uma concepção norte-americana, seja como a marionete a ser manipulada na europeia.

Esses modelos nos quais nossas bases foram construídas, trazem problemáticas não resolvidas. Para Braga (1992), as dificuldades no ensino de Comunicação, quaisquer que sejam as habilitações, são reflexos da dualidade do campo: a visão teórico-sociológica crítica e as necessidades de mercado do modo capitalista de produção cultural da sociedade. De um lado, lidamos com uma visão teórica recusadora dos processos de comunicação de massa, e por outro lado, temos uma produção cultural com enormes avanços tecnológicos, que deixa em segundo plano a reflexão e o desenvolvimento de teorias. Diante desse impasse, vivemos o que Braga (1992) denominou de esquizofrenia do campo da Comunicação, em que

Nosso verdadeiro problema é o de construir (e não apenas na estrutura do currículo, mas também na caracterização do campo da comunicação) as coerências mínimas, as linhas de integração necessárias à superação da atual esquizofrenia. Sem o que, o campo da comunicação poderá ser sempre reduzido seja a uma perspectiva como segmento do mercado, seja a uma das ciências que têm nos fornecido suas bases teórico-metodológicas. Ou seja, a rigor, não existiria o campo da comunicação, mas apenas um objeto peculiar dentro de uma ciência já estabelecida, ou então uma área de especialização profissional (Braga, 1992, p. 154).

Dessa maneira, ao longo do tempo, o ensino de Comunicação já sofreu inúmeras transformações, mas está distante de um equilíbrio, não só em decorrência dos currículos mínimos e diretrizes curriculares implementados no curso, como também devido a dualidade teórica que causa a esquizofrenia apontada por Braga, e ainda, por conta da dicotomia teoria e prática que observamos no ensino da área.

\footnotetext{
Alunos queixam-se de que recebem aulas com críticas negativas aos meios de comunicação e, depois, aprendem como usar estes meios repetindo as mesmas fórmulas do mercado. Em decorrência disso, o que se vê, analisando os currículos, é que existe uma dissonância entre a formação técnica e a formação crítica. Nas disciplinas teóricas os alunos discutem a sociedade de consumo sob a perspectiva crítica e, nas técnicas e práticas, eles a vêem sob a perspectiva pragmática, de otimização de resultados através da motivação ao consumo e do fomento de vendas (Gomes, 2007, p. 157).
}

É possível constatar que o ensino de Publicidade e Propaganda está baseado na teoria e na prática, em que dependendo das condições de cada instituição de ensino, cada aspecto é desenvolvido com maior ou menor ênfase, em um processo que, em sua grande maioria, é marcado pelo desequilíbrio. Geralmente a teoria é trabalhada mais relacionada à comunicação com um todo, em detrimento do tratamento de questões específicas e da articulação entre elas, ignorando, por exemplo, diferenças conceituais, como explicitado no caso das definições de Publicidade e Propaganda. 
Com esta prática claramente discriminatória de reflexões mais teóricas e, portanto, mais críticas, os conteúdos teóricos ligados diretamente ao conjunto sobre a Publicidade são pouco explorados e repassados aos alunos, muitas vezes, de forma não muito estimulante, criando uma aversão crônica, e fortalecendo o mito de que o estudo da publicidade deve ser mais técnico e prático e, que alunos deste curso não gostam de leituras, discussões teóricas, reflexões críticas etc. (Gomes, 2002, pp. 76-77).

Como discute Trindade (2017), a Publicidade e Propaganda é um campo ambivalente, que aparenta ser desconexo e voltado à lógica administrativa das ferramentas publicitárias e do mercado, ao mesmo tempo que desenvolve uma pesquisa sólida e coesa, mas com pouca expressão na academia por conta da lógica e da prioridade em torno da formação profissional.

Esse desequilíbrio pode ser oriundo das exigências do mercado, que busca um profissional à sua imagem e semelhança, e reclama da formação dada na universidade, afirmando que os alunos só aprendem de fato quando estão no mercado e desenvolvem a experiência prática. Mas é preciso que se tenha em mente que a função de uma universidade e do Ensino Superior ultrapassa a questão profissional e se preocupa também com a formação crítica do cidadão e de suas responsabilidades sociais. Para Petermann (2020), faz-se necessário educar para a diversidade e para a construção de uma sala de aula em transformação constante para se acompanhar a complexidade da sociedade.

Portanto, devemos refletir sobre os processos de formação de maneira a agregar teoria e prática, encontrar modos "que trabalhem a prática e desenvolvam a teoria desta prática; que informem sobre teorias, mas, ao mesmo tempo, busquem a sua verificação a partir dos dados empíricos e históricos da realidade" (Braga, 1992, p. 155). Diante disso, precisamos buscar caminhos para o ensino em Comunicação, necessitamos pensar os processos comunicativos para além da simples ferramenta, a que foi submetida pelo Marketing, que em uma visão reducionista aborda o ensino de uma técnica (Gomes, 2002).

Dessa maneira, todo o processo de formação segue um caminho incerto. Com essa oposição entre teoria e prática, temos um cenário em que ambos os lados não conseguem se desenvolver até certo ponto, no qual temos perfis estereotipados e cheios de equívocos de um lado e de outro. A figura do pesquisador imerso em suas teorias dentro da sua sala ou laboratório e o profissional que não pensa e apenas tem a função de apertar botões.

Como Braga (2006) ressalta, não podemos ver esses dois modos como independentes entre si: a teoria como uma forma de conhecimento e a prática como o fazer. Ambas são tanto modos de conhecimento quanto modos de fazer, em que dificilmente podemos conhecer ou fazer, isoladamente, através de um único processo. "O âmbito da teoria exige contextualização, exige posições praxiológicas, exige fazeres e reflexividade. O âmbito das práticas impõe experimentação. Enfrentamento de desafios, boas competências do aprender e reflexão" (Braga, 2006, p. 22).

Não há razão para refletirmos ou desenvolvermos teorias se elas não respondem a questões relacionadas às nossas vidas e às nossas práticas. A pesquisa necessita de contextualização e finalidades sociais. Por outro lado, o fazer não pode vir desacompanhado de reflexão, pois

O melhor profissional de Comunicação não é aquele que dispõe de melhores informações prontas sobre o que fazer, mas quem transfere suas informações para situações variadas, muito específicas, sendo capaz de aprender, a partir do próprio problema de ação de enfrentar seus desafios específicos (Braga, 2006, p. 24).

Para lidar com problemas complexos na sociedade, os profissionais precisam compreender o poder da comunicação na atualidade. Viegas (2018) propõe que a didática em cursos de Publicidade e Propaganda devem ir muito além de um ensino tecnicista, mas também não se pode se restringir aos estudos de teorias.

É necessário fomentar a capacidade de aprender e de se apropriar das experiências vividas e ressignificá-las em diferentes contextos, a partir de um conhecimento vivo (Morin, 2010), um conhecimento que se move e enfrenta outras situações. "A ciência não tem apenas uma verdade, mas sim várias verdades provisórias, onde a única verdade é aceitar essa 
regra e essa investigação" (Morin, 2010, p. 104). Assim, o conhecimento científico se dá através de um processo dinâmico, na qual a sua base reside no fato de que tudo é questionável e mutável.

\section{Considerações Finais}

Nossa aproximação para a realização do estudo apresentado se deu pela tentativa de entender a complexidade que envolve a Publicidade e a Propaganda e procurou refletir sobre a questão da incoerência já indicada no título da habilitação, em que há apontamentos para duas práticas distintas, mas que uma se sobrepõe a outra. Parece não fazer sentido termos um curso de Publicidade e Propaganda se elas se referem à mesma atividade. Por outro lado, nos causou estranheza o fato de serem duas práticas distintas, e após a conclusão da graduação, o profissional ser convencionalmente denominado de publicitário, qualquer que seja a sua linha de atuação. Apesar de Publicidade e Propaganda coexistirem e se utilizarem de estratégias e linguagens semelhantes, são práticas distintas e se faz necessário conhecer cada uma delas.

Como discutimos antes, esse fenômeno pode ser justificado pelo papel central da Publicidade na nossa sociedade e das demandas que surgiram a partir disso, em detrimento da Propaganda, que teve também uma grande importância, mas de forma menos visível, pois esteve intimamente ligada aos fatos políticos. Se por um lado, a Publicidade atraía para si todos os holofotes, a Propaganda ficava nos bastidores. É importante salientar que no âmbito político, no qual a Propaganda tem espaço de extrema relevância, não há a confusão de nomenclaturas e conceitos. Nunca ouvimos Publicidade Política, por exemplo, para se referir à Propaganda Política.

Diante disso, foi necessário conhecer, mesmo que ainda inicialmente, as origens históricas para entender suas implicações no presente e as lógicas de ensino na área. Nessa perspectiva, é importante compreender tanto a intrínseca relação da Publicidade e Propaganda com o mercado e com o fato político, quanto o inverso. E ainda, compreender o papel preponderante que a Publicidade desempenhou e continua desempenhando, por isso o seu destaque em detrimento da Propaganda, nos meios massivos de comunicação, no qual é responsável por girar todo o capital financeiro que sustenta a estrutura dos mais diversos setores. Para além disso, tornou-se imprescindível reflexões sobre o capital simbólico dessas duas práticas, e sobretudo, as suas inserções sociais e principalmente enquanto construtoras culturais.

Portanto, nesse cenário, temos conflitos de várias ordens: primeiro, a falta de clareza da atividade, regulamentada por lei, do agenciador de propaganda e a eventual defasagem do profissional; em seguida o equívoco no uso dos termos Publicidade e Propaganda, utilizados como sinônimos mesmo se referindo a atividades diferentes; e ainda, mesmo que houvesse a distinção dos conceitos, a pessoa que trabalha com Propaganda não tem qualquer tipo de reconhecimento, pois não importa a sua atuação, o profissional é denominado de publicitário.

Outra confusão de terminologia está em torno do propagandista, que teoricamente seria o profissional que exerce a função equivalente ao publicitário, sendo um direcionado à Publicidade e o outro à Propaganda (partindo do pressuposto que são práticas diferentes). No entanto, não há propagandistas nesse sentido. O termo, no Brasil, refere-se àquele que trabalha para laboratórios de medicamentos percorrendo consultórios e clínicas médicas, distribuindo amostras e promovendo a divulgação comercial do produto, tendo, nessa perspectiva, pouco status e sendo considerada uma profissão inferior (Gomes et al., 1998). É curioso apontar, que nesse caso, mesmo quando se faz referência ao propagandista, a sua atividade mais uma vez não corresponde com o conceito de Propaganda, mas se aproxima do de Publicidade.

Dessa forma, a pouca clareza das distinções entre essas duas práticas impede que sejam encaradas como processos que vão além do mero objetivo mercadológico ou do controle político. É preciso que se reflita as dimensões social e cultural dessas atividades como construtoras de identidades. 
Todas essas questões têm implicações diretas no ensino da área, em que seu direcionamento acaba seguindo rumos predominantemente mercadológicos, muitas vezes até instrumentais, por conta de toda a relação histórica, financeira e cultural com o mercado. Mais do que isso, temos um sério problema de formação na área da Comunicação de um modo geral, com agravantes na Publicidade e Propaganda. A questão do descompasso existente entre teoria e prática no ensino é visível, decorre de duas perspectivas teóricas opostas: de um lado uma visão crítica que recusa os processos de comunicação de massa, de outro, processos de produção cultural com enormes avanços tecnológicos baseado na otimização de resultados (Braga, 1992).

Dessa maneira, essas questões se entrelaçam e fazem com que a temática do ensino de Publicidade e Propaganda seja uma discussão complexa, cercada por conflitos tanto teóricos, conceituais e de nomenclatura, quanto históricos, sociais e culturais, desde as suas origens e em meio às suas transformações ao longo da história.

Diante disso, a formação em Comunicação permanece como um grande desafio. É necessário desmistificar os polos antagônicos estabelecidos entre teoria e prática no ensino na área, e especialmente em Publicidade e Propaganda. Precisamos formar novos olhares em que os processos e as perspectivas sejam cada vez mais agregadoras, de forma a percebermos as partes para pensarmos no todo. Precisamos construir nossas percepções e trabalhar de maneira integrada teoria e prática, buscando um equilíbrio em que ambas as partes possam construir juntas os processos de ensino, aprendizagem e formação.

\section{Referências}

Braga, J. L. (1992). A formação de professores para a Comunicação. In M. M. K. Kunsch (Org.), O Ensino de Comunicação: análises, tendências e perspectivas. ABECOM.

Braga, J. L. (2006). Ensino e pesquisa em Comunicação: da teoria versus prática à composição contexto \& profissão. Revista Comunicação \& Educação. São Paulo.

Brasil. (1965). Lei $n^{\circ} 4.680$, de 18 de junho de 1965. Dispõe sobre o exercício da profissão de Publicitário e de Agenciador de Propaganda e dá outras providências.

Castells, M. (1999). A sociedade em rede. Paz e Terra.

Creswell, J. W. (2007). Projeto de pesquisa: métodos qualitativo, quantitativo e misto. Artmed.

Gil, A. C. (1999). Métodos e técnicas de pesquisa social. Atlas.

Gomes, N. D. (2001). Publicidade ou propaganda? É isso aí! Revista Famecos. Porto Alegre.

Gomes, N. D. (2002). Reflexões sobre o ensino da Publicidade e Propaganda. Revista Animus. Santa Maria.

Gomes, N. D. (2007). Pensando o ensino de Publicidade e Propaganda: contribuições da academia e do mercado para uma melhor sintonia. In M. M. K. Kunsch (Org.), Ensino de Comunicação: qualidade na formação acadêmico-profissional. Intercom.

Gomes, N. D, Corrady, A, \& Cury, L. F. (1998). A dialética conceitual da Publicidade e da Propaganda. In Intercom - Sociedade Brasileira de Estudos Interdisciplinaridades da Comunicação. Anais XXI Congresso Brasileiro de Ciências da Comunicação - Recife, PE.

Gonçalez, M. C. (2009). Publicidade e Propaganda. IESDE Brasil.

Lacerda, M. B. (2008). Publicidade na ditatura: crítica e resistência no Regime Militar. [Dissertação de Mestrado em Comunicação e Linguagens, Universidade Tuiuti do Paraná]. Curitiba.

Marques de Melo, J. (1992). Modernidade ou anacronismo? Dilema do ensino de comunicação nos anos 90 . In M. M. K. Kunsch (Org.), O Ensino de Comunicação: análises, tendências e perspectivas. ABECOM.

Martensen, R. L. (1990). O ensino de propaganda no Brasil. In R. Castelo branco, R. L. Martensen, \& F. Reis (Org.), História da Propaganda no Brasil. Ibraco.

Martín-Barbero, J. (2009). Dos meios às mediações: comunicação, cultura e hegemonia. Editora UFRJ.

Morin, E. (2010). Ciência com Consciência. Bertrand Brasil.

Muniz, E. (2004). Publicidade e Propaganda - Origens históricas. http://www.eloamuniz.com.br/arquivos/1188171156.pdf.

Ortiz, R. (1991). A moderna tradição brasileira: Cultura Brasileira e Indústria Cultural. Editora Brasiliense. 
Pedrini, I. A. D., \& Malusá, S. (2019). O ensino e a aprendizagem antes do curso superior em Publicidade e Propaganda: o paradigma do ensino pela prática (1900 - 1960). Revista Animus. Santa Maria.

Petermann, J. (2019). Desafios ao ensino da Publicidade na contemporaneidade. In Associação Brasileira de Pesquisadores em Publicidade (ABP2). X Encontro Nacional de Pesquisadores em Publicidade e Propaganda - São Paulo, SP.

Pimentel, A. (2001). O método da análise documental: seu uso numa pesquisa historiográfica. Cadernos de pesquisa.

Pinho, J. B. (1998). Trajetória e demandas do ensino de graduação em Publicidade e Propaganda no Brasil. In P. R. Tarsitano (Org.), Publicidade: análise da produção publicitária e da formação profissional.

Trindade, E. (2017). Didática e diversidade no curso de publicidade e propaganda. Estratégias pedagógicas para a formação de profissionais críticos. Revista Latinoamericana de Ciencias de la Comunicación (ALAIC). Lorena.

Vaz, R. M. A. M. (2002). O papel social da propaganda política como legitimadora do poder. In Intercom - Sociedade Brasileira de Estudos Interdisciplinaridades da Comunicação. IX Simpósio Regional de Pesquisa em Comunicação - Campos dos Goytacazes, RJ.

Versiani, F. R., \& Suzigan, W. (1990). O processo brasileiro de industrialização: uma visão geral. http://www.angelfire.com/id/SergioDaSilva/industrializacao.pdf.

Viegas, P. (2018). Didática e diversidade no curso de publicidade e propaganda: estratégias pedagógicas para a formação de profissionais críticos. Revista ECCOM. São Paulo.

Vitalli, T. C. (2007). O desafio do ensino superior de Publicidade para o século XXI. In C. Perez, \& I. S. Barbosa (Org.), Hiperpublicidade: fundamentos e interfaces. Thomson Learning. 